\title{
Social Responsibility among University Students: An Empirical Study of Spanish Samples
}

\author{
José Manuel García Ramos, \\ Carmen de la Calle Maldonado, \\ María Consuelo Valbuena Martínez and \\ Teresa de Dios Alija
}

Additional information is available at the end of the chapter

http://dx.doi.org/10.5772/intechopen.75115

\begin{abstract}
The Universidad Francisco de Vitoria (UFV) has developed an educational project that is unique in Europe which integrates social responsibility as an obligatory subject across all university courses. The goal of this course is to heighten university students' awareness of social commitment and responsibility so that all individuals gain an understanding of the ideas presented and subsequently adopt these values, making them their own and applying them in their future professional life. Our aim is to evaluate the impact of this education on our students. To do this, we used a valid, reliable tool that with a personal questionnaire, (sample size: 757 students) allowed the information to be collected at two different moments in time (pretest and posttest). The results show that the social responsibility module has a significant impact on students with the effect varying depending on the degree being studied.
\end{abstract}

Keywords: university education, social responsibility, university students, social impact, construct validity

\section{Introduction}

University education is more than just technical instruction to prepare students for a professional career; it should also contribute to students' overall personal development. Because of this, the syllabuses for the courses offered at the Universidad Francisco de Vitoria include a set of subjects with a humanist character aimed at fostering a series of values, attitudes and habits 
in students that will in future enable them to think with rigour, comprehensively understanding and analysing reality and so also be able to take personal and professional decisions through the prism of ethical responsibility.

Students cannot turn their backs on social problems that affect their surroundings. They must be prepared to provide specific, committed solutions for the common good through the exercise of their profession.

\subsection{Theoretical review}

This study is based on an analysis of the impact of training in Social Responsibility for University Students (SREU) and not on the impact of what is known as University Social Responsibility (USR), which focusses more on corporate, institutional or business responsibility [1].

Regarding the former, we have found studies relating to the impact of ethics education, such as the works by Pascarella, Ethington and Smart [2] that analyse the influence of universities in training humanitarian values [3], the effects of volunteering during student years [4], the role of classes in education for personal and social responsibility [5], and the promotion of gifts and talents related to social support and humanitarian advocacy [6].

In 2013 an extensive review of literature of the role of higher education in tutoring personal and social responsibility [5] was presented from which interesting conclusions can be drawn about the impact of learning about social responsibility and personal development of students in the context of the change they encounter in higher education [7].

Regarding the evaluation of students' training in social responsibility, it is necessary to cite the analysis of the efficacy of the Social Responsibility module at the UFV in relation to the students' overall development [8], the works by Larrán and others on the availability and impact of social responsibility and business ethics modules in certain courses from the field of organisation management [9], development cooperation as a methodology for teaching engineers social responsibility [10], and the analysis of challenges and opportunities that Gordon and Doyle [11] present concerning the teaching of personal and social responsibility and the transfer of education and research in the validation of the Social Responsibility for University Students construct.

In 2015, Buyolo [12] noted that of the 71 Spanish universities that had implemented the Business Management course, only 24 offered some sort of module relating to corporate social responsibility, and of this $32 \%$, only the UFV had established continuous evaluation including the internalisation of values and aptitudes, as Echainiz Barrondo states "The important thing is not to know what is good, but to do what is good".

Other pieces of research provide models for analysing the impact of using active methodologies, like our social practices on students' learning [13], or processes for validating instruments for evaluating cooperative work, which is one of the methods we use in the social responsibility module at the Universidad Francisco de Vitoria [14]. 


\subsection{Subject matter}

Our goal with the Social Responsibility module is not to try to teach the value of social commitment but instead to help students "discover it themselves" [15] so that the value of SREU is not imposed from outside as something alien and external.

In light of this, this module is approached from a broad perspective that integrates three different and complementary areas for development: the classroom, social practices and mentoring, with the idea that students will connect the theory from the classroom and their experience of social practices with their everyday lives.

The goal of the classroom-based lessons is to inspire students to reflect on the meaning of social responsibility, starting with respect for human dignity.

The objective of the social practices is to provide personal experience of the possibility of doing something concrete to contribute to improving society. Therefore, each student is assigned a social project he or she must participate in throughout the whole year in cooperation with an NGO.

Through the mentoring, we aim to illuminate the students' personal experience from the practices to link it to their current university experience and professional future.

To measure the level of change the student underwent after taking this module we prepared a scale to evaluate social responsibility.

The first step in constructing the scale to evaluate the level of SREU was to determine the features that define this variable. To do this, the information obtained through personal monitoring of students who had taken the module in previous years was used.

Once the dimensions of the SREU concept were defined, the items on the scale were established.

The resulting survey instrument (ANNEXE 1) is structured around the four dimensions of the SREU construct [16].

- Commitment to others and my surroundings

- Personal discovery of values

- Education in social responsibility

- Approaching my professional activity from a position of social commitment

- Opinion item

This provides an overall evaluation of the student's level of social responsibility. This item is presented as an opinion variable. A good measurement of the level of commitment and social responsibility of university students must result in high and significant correlations between each of the items and the opinion item, as well as between average of the items and the opinion item. 


\section{Method, hypothesis and results}

\subsection{Goals}

The general goal of this study is to evaluate the impact of taking the SREU module on students from a variety of university courses, using a reliable and valid tool.

The specific goals are:

- To measure whether different courses have an impact.

- To find possible common patterns between courses regarding the factors that comprise SREU.

\subsection{Hypothesis}

There are three main hypotheses to compare in this study. They relate to three types of possible impact: (1) the module has a general impact on the students; (2) the different dimensions that make up SREU have different impacts on the students; and (3) the module has a different impact on the students in each course.

\section{Method}

\subsection{Instrument}

The proposed measurement instrument is based around four dimensions and 21 items as stated above. The reliability and validity studies for the instrument used show rates of internal consistency that are more than acceptable or satisfactory (between 0.85 and 0.92, overall reliability) and the exploratory and confirmatory factor analyses indicate the presence of a single construct, based on three correlated dimensions, explaining $42.38 \%$ of the variance. The principal components analysis procedure was used as a factor extraction method. The direct Oblimin factor rotation method was used.

The indices analysed to evaluate fit (Chi-squared/degrees of freedom, TLI, CFI and RMSEA) show that this is the model with the best fit.

A detailed study into the reliability and validity of this instrument is provided in García Ramos et al. [17].

\subsection{Population, sample and data collection process}

The study population comprises second-year students at the UFV who are taking this module. A total of 639 students were enrolled in this module in the 2012-2013 academic year. The sample was selected through a quota sampling process, taking the course as the main 
characteristic, in which the sample should be similar to the study population, second year students at the UFV.

The information was collected using an individual survey. The field work was performed two times: (1) in October 2012 it was performed on the students when teaching of the module had recently started (pretest) and (2) in May 2013 it was performed a second time when the students had completed the module (posttest). The samples from the pretest and the posttest are independent as the questionnaires are anonymous and the individuals who answered the pretest and posttest are not identified to make comparison of the samples possible. Table 1 shows the technical details of the sampling.

A total of 757 surveys was eventually obtained: 404 surveys in the pretest $(63.2 \%$ of the population) and 353 surveys in the posttest (55.2\% of the population). The following profile of the sample was subsequently identified (Table 2).

\subsection{Data analysis process}

The SPSS version 21 statistics program was used to codify and analyse the data (SPSS Inc., Chicago, USA). Descriptive analyses were performed (central tendency measures and standard deviation). To compare the significant differences at the statistical level between the two moments (before and after taking the module), Student's t-test for independent samples and one factor and two factor Analyses of Variance (ANOVA) parametric tests were used to analyse the differences. The assumptions of independence of the data (normality and homoscedasticity) were tested. Student's t-test was performed, without distinguishing between courses, on an aggregate dimension (the sum of the four dimensions). One-factor analyses of variance (ANOVA) were performed on each of the four dimensions and on the opinion item. For these six quantitative variables, two-factor ANOVA analyses were performed to evaluate the effects of the two possible sources of variance, as well as the interaction between them: (A) belonging to the pretest or posttest groups and (b) belonging to a particular course. One-factor ANOVA analyses were also performed on the four dimensions and the opinion item for each of the courses. A confidence level of $95 \%$ or higher was used in almost all of the analyses.

\begin{tabular}{ll}
\hline Characteristics & Survey \\
\hline Universe & Second year students at the UFV who are taking the social responsibility module \\
Sampling process & By quotas Stratification by course \\
Data collection & Individual survey of the students in class \\
Sample size & 404 (pretest) $/ 353$ (posttest) surveys collected \\
Sampling error & $\pm 3 \%$ \\
Confidence level & $95 \%$ for the most unfavourable case $\mathrm{p}=\mathrm{q}=0.5$ \\
Field Work & November 2012 (pretest) and May 2013 (posttest) \\
\hline
\end{tabular}

Table 1. Technical details of the research project. 


\begin{tabular}{|c|c|c|c|c|}
\hline \multirow[t]{2}{*}{ Courses } & \multicolumn{2}{|c|}{ Pretest } & \multicolumn{2}{|c|}{ Posttest } \\
\hline & $\mathbf{N}$ & $\%$ & $\mathbf{N}$ & $\%$ \\
\hline Business Management (BM) & 31 & 7.67 & 24 & 6.80 \\
\hline Biotechnology (BIO) & 41 & 10.15 & 41 & 11.61 \\
\hline Sport and Physical Activity Sciences (SPPA) & 63 & 15.59 & 46 & 13.03 \\
\hline Audiovisual Communication (AUD) & 37 & 9.16 & 49 & 13.88 \\
\hline Law (LAW) & 20 & 4.95 & 20 & 5.67 \\
\hline Design and Fine Arts (DES + FA) & 39 & 9.65 & 29 & 8.22 \\
\hline Pre-school and Primary Education (EDU) & 41 & 10.15 & 21 & 5.95 \\
\hline BM+ Law (Excellens) (EXC) & 9 & 2.23 & 10 & 2.83 \\
\hline Physiotherapy (PHY) & 38 & 9.41 & 37 & 10.48 \\
\hline Computer science (COM) & 15 & 3.71 & 15 & 4.25 \\
\hline Marketing (MAR) & 10 & 2.48 & 11 & 3.12 \\
\hline Journalism (JOU) & 49 & 12.13 & 34 & 9.63 \\
\hline Marketing (MAR) & 11 & 2.72 & 16 & 4.53 \\
\hline
\end{tabular}

Table 2. Profile of the sample.

\section{Results}

\subsection{Descriptive statistics}

Tables 3 and 4 show the descriptive statistics of the dimensions of the pretest and posttest for the different courses. The scores for each dimension were calculated as the sum of the items they comprise.

All of the courses have an average social commitment level of over 4.1 in all dimensions, in both the pretest and the posttest, with a few exceptions.

In general, on all of the courses, the average level of satisfaction for each dimension is higher in the posttest than the pretest, apart from a few minor exceptions.

Therefore, the descriptive results seem to indicate possible differences of means between the pretest and the posttest for almost all of the courses. These preliminary results require the use of inferential data processing methods that make it possible to decide whether the differences are significant or not.

\subsection{Comparison of mean difference for the evaluation of general impact}

To test the general impact hypothesis between the pretest and posttest, the aggregate dimension as the sum of the four dimensions was calculated and Student's t test was performed. The 


\begin{tabular}{|c|c|c|c|c|c|c|c|c|c|c|c|c|c|}
\hline \multicolumn{14}{|l|}{ Course } \\
\hline & & $\begin{array}{l}\text { BM } \\
\text { (PR) }\end{array}$ & $\begin{array}{l}\text { BM } \\
\text { (PO) }\end{array}$ & $\begin{array}{l}\text { BIO } \\
\text { (PR) }\end{array}$ & $\begin{array}{l}\text { BIO } \\
\text { (PO) }\end{array}$ & $\begin{array}{l}\text { SPPA } \\
\text { (PR) }\end{array}$ & $\begin{array}{l}\text { SPPA } \\
\text { (PO) }\end{array}$ & $\begin{array}{l}\text { AUD } \\
\text { (PR) }\end{array}$ & $\begin{array}{l}\text { AUD } \\
\text { (PO) }\end{array}$ & $\begin{array}{l}\text { LAW } \\
\text { (PR) }\end{array}$ & $\begin{array}{l}\text { LAW } \\
\text { (PO) }\end{array}$ & $\begin{array}{l}\text { DES + FA } \\
\text { (PR) }\end{array}$ & $\begin{array}{l}\text { DES + FA } \\
\text { (PO) }\end{array}$ \\
\hline & $\mathrm{N}$ & 31 & 24 & 41 & 41 & 63 & 46 & 37 & 49 & 20 & 20 & 39 & 29 \\
\hline \multirow[t]{4}{*}{ DIM 1} & $\bar{X}$ & 4.3 & 4.4 & 4.4 & 4.7 & 4.1 & 4.6 & 4.1 & 4.7 & 3.9 & 5.3 & 4.4 & 4.8 \\
\hline & $S$ & 0.71 & 0.72 & 0.77 & 0.77 & 0.86 & 0.61 & 0.65 & 0.60 & 0.70 & 0.55 & 0.66 & 0.60 \\
\hline & Mode & 3.8 & 4.0 & 4.2 & 4.6 & 4.4 & 4.4 & 4.0 & 4.6 & 4.0 & 5.4 & 4.6 & 5.2 \\
\hline & Mdn & 4.4 & 4.5 & 4.4 & 4.6 & 4.2 & 4.6 & 4.2 & 4.8 & 4.0 & 5.4 & 4.6 & 4.8 \\
\hline \multirow[t]{4}{*}{ DIM 2} & $\bar{X}$ & 4.5 & 4.6 & 4.8 & 5.1 & 4.5 & 4.9 & 4.6 & 5.0 & 4.4 & 5.5 & 4.8 & 5.2 \\
\hline & S & 0.72 & 0.85 & 0.81 & 0.78 & 0.77 & 0.71 & 0.67 & 0.65 & 0.80 & 0.42 & 0.70 & 0.66 \\
\hline & Mode & 4.2 & 5.6 & 5.6 & 5.4 & 4.6 & 4.2 & 4.6 & 4.8 & 4.0 & 5.8 & 5.2 & 5.0 \\
\hline & Mdn & 4.6 & 4.7 & 5.0 & 5.2 & 4.6 & 4.8 & 4.6 & 5.0 & 4.4 & 5.6 & 4.6 & 5.2 \\
\hline \multirow[t]{4}{*}{ DIM 3} & $\bar{X}$ & 4.1 & 4.5 & 4.2 & 4.5 & 4.1 & 4.5 & 3.9 & 4.3 & 4.1 & 5.4 & 4.0 & 4.2 \\
\hline & S & 0.98 & 0.75 & 1.11 & 1.14 & 0.99 & 0.84 & 0.92 & 0.83 & 0.73 & 0.39 & 0.91 & 0.73 \\
\hline & Mod. & 3.2 & 4.6 & 4.4 & 4.8 & 4.6 & 4.8 & 3.8 & 4.8 & 3.0 & 5.6 & 3.2 & 4.4 \\
\hline & Mdn & 4.0 & 4.6 & 4.4 & 4.8 & 4.2 & 4.5 & 4.0 & 4.4 & 4.1 & 5.5 & 4.2 & 4.4 \\
\hline \multirow[t]{4}{*}{ DIM 4} & $\bar{X}$ & 4.4 & 4.6 & 4.6 & 5.0 & 4.5 & 4.8 & 4.5 & 4.7 & 4.8 & 5.5 & 4.8 & 4.8 \\
\hline & S & 0.86 & 0.96 & 1.03 & 0.71 & 0.92 & 0.69 & 0.68 & 0.66 & 0.65 & 0.34 & 0.81 & 0.73 \\
\hline & Mod. & 3.8 & 3.6 & 4.6 & 4.6 & 4.8 & 4.4 & 4.4 & 4.4 & 5.4 & 5.2 & 5.6 & 5.0 \\
\hline & Mdn & 4.4 & 4.4 & 4.8 & 5.0 & 4.6 & 4.8 & 4.4 & 4.8 & 4.8 & 5.5 & 4.8 & 5.0 \\
\hline
\end{tabular}

Table 3 Statistics for dimensions by course (pretest (PR) and posttest (PO)).

result of the comparison indicates that there is a significant difference in favour of the posttest. See Table 5.

A factorial analysis of variance was also performed. This model evaluates the individual and joint effect of two or more factors (course and group) on a quantitative dependent variable (item 21 or dimension).

In this case, it makes it possible to establish whether the interaction between the group factors (pretest/posttest) and course affects the dependent variable.

If the p-values are below 0.05 , this indicates that the groups defined by pretest and posttest have significantly different average results and that the average results between courses are also significantly different. The information on the effect of the group*course interaction indicates that the differences in the results with the provision of the social responsibility module that appear between the pretest and the posttest, in favour of the posttest, are not the same between courses, or, in other words, the differences between courses are not the same in the two groups (pretest and posttest). See Table 6. 


\begin{tabular}{|c|c|c|c|c|c|c|c|c|c|c|c|c|c|c|c|}
\hline \multicolumn{16}{|l|}{ Course } \\
\hline & & $\begin{array}{l}\text { EDU } \\
\text { (PR) }\end{array}$ & $\begin{array}{l}\text { EDU } \\
\text { (PO) }\end{array}$ & $\begin{array}{l}\text { EXC } \\
\text { (PR) }\end{array}$ & $\begin{array}{l}\text { EXC } \\
\text { (PO) }\end{array}$ & $\begin{array}{l}\text { PHY } \\
\text { (PR) }\end{array}$ & $\begin{array}{l}\text { PHY } \\
\text { (PO) }\end{array}$ & $\begin{array}{l}\text { INF } \\
\text { (PR) }\end{array}$ & $\begin{array}{l}\text { INF } \\
\text { (PO) }\end{array}$ & $\begin{array}{l}\text { MAR } \\
\text { (PR) }\end{array}$ & $\begin{array}{l}\text { MAR } \\
\text { (PO) }\end{array}$ & $\begin{array}{l}\text { JOU } \\
\text { (PR) }\end{array}$ & $\begin{array}{l}\text { JOU } \\
\text { (PO) }\end{array}$ & $\begin{array}{l}\text { MAR } \\
\text { (PR) }\end{array}$ & $\begin{array}{l}\text { MAR } \\
\text { (PO) }\end{array}$ \\
\hline & $\mathrm{N}$ & 41 & 21 & 9 & 10 & 38 & 37 & 15 & 15 & 10 & 11 & 49 & 34 & 16 & 11 \\
\hline \multirow[t]{4}{*}{ DIM 1} & $\bar{X}$ & 4.9 & 5.3 & 4.6 & 4.8 & 4.3 & 4.8 & 3.3 & 4.1 & 4.5 & 5.3 & 4.5 & 4.8 & 5.0 & 3.9 \\
\hline & $S$ & 0.65 & 0.47 & 0.43 & 1.03 & 0.87 & 1.04 & 1.27 & 1.04 & 0.99 & 0.48 & 0.86 & 0.81 & 0.93 & 0.52 \\
\hline & Mode & 5.0 & 5.2 & 4.2 & 5.0 & 3.6 & 4.6 & 2.6 & 4.8 & 4.8 & 5.4 & 4.8 & 4.6 & 4.6 & 3.6 \\
\hline & Mdn & 5.0 & 5.2 & 4.6 & 5.1 & 4.4 & 5.0 & 3.2 & 4.6 & 4.8 & 5.4 & 4.6 & 5.0 & 4.9 & 3.6 \\
\hline \multirow[t]{4}{*}{ DIM 2} & $\bar{X}$ & 5.2 & 5.6 & 5.2 & 5.1 & 4.9 & 5.0 & 3.6 & 4.2 & 4.9 & 5.4 & 4.9 & 5.1 & 5.5 & 4.7 \\
\hline & S & 0.57 & 0.36 & 0.61 & 0.95 & 0.85 & 1.04 & 1.17 & 0.97 & 0.82 & 0.37 & 0.85 & 0.73 & 0.77 & 0.47 \\
\hline & Mode & 4.6 & 5.6 & 4.6 & 6.0 & 5.4 & 6.0 & 2.6 & 4.4 & 3.6 & 5.4 & 5.8 & 6.0 & 5.6 & 3.8 \\
\hline & Mdn & 5.2 & 5.6 & 5.4 & 5.3 & 5.0 & 5.2 & 3.6 & 4.4 & 5.3 & 5.4 & 5.0 & 5.2 & 5.6 & 4.6 \\
\hline \multirow[t]{4}{*}{ DIM 3} & $\bar{X}$ & 4.6 & 5.2 & 4.6 & 4.7 & 4.0 & 4.7 & 3.1 & 3.8 & 4.3 & 5.2 & 4.2 & 4.6 & 4.9 & 3.4 \\
\hline & $S$ & 1.03 & 0.52 & 0.54 & 1.00 & 0.99 & 1.04 & 1.28 & 1.21 & 0.84 & 0.46 & 0.93 & 1.05 & 1.16 & 1.01 \\
\hline & Mode & 5.0 & 4.6 & 4.4 & 4.6 & 3.0 & 4.8 & 4.0 & 4.4 & 4.2 & 5.4 & 4.0 & 4.6 & 5.4 & 2.8 \\
\hline & Mdn & 4.8 & 5.2 & 4.8 & 4.8 & 4.1 & 4.8 & 2.8 & 4.2 & 4.2 & 5.2 & 4.2 & 4.6 & 5.4 & 3.0 \\
\hline \multirow[t]{4}{*}{ DIM 4} & $\bar{X}$ & 5.0 & 5.5 & 5.0 & 5.0 & 5.0 & 5.0 & 3.7 & 4.3 & 4.7 & 5.3 & 5.1 & 5.0 & 5.2 & 3.9 \\
\hline & S & 0.76 & 0.34 & 0.68 & 1.21 & 0.77 & 1.06 & 1.17 & 1.10 & 0.99 & 0.42 & 0.70 & 0.89 & 0.89 & 0.65 \\
\hline & Mode & 6.0 & 5.6 & 4.4 & 6.0 & 4.8 & 6.0 & 2.4 & 4.2 & 4.8 & 5.2 & 4.8 & 6.0 & 5.6 & 3.2 \\
\hline & Mdn & 5.2 & 5.6 & 5.2 & 5.5 & 5.0 & 5.2 & 3.4 & 4.4 & 4.8 & 5.2 & 5.2 & 5.2 & 5.4 & 3.6 \\
\hline
\end{tabular}

Table 4. Descriptive statistics for dimensions by course (pretest (PR) and posttest (PO)).

\begin{tabular}{lllllllll}
\hline & & \multicolumn{2}{l}{$\begin{array}{l}\text { Levene's equality of } \\
\text { variances test }\end{array}$} & & \multicolumn{2}{l}{ T test for equal means } & & Significant direction \\
\cline { 2 - 7 } & $\mathbf{F}$ & Sig. & $\mathbf{t}$ & $\mathbf{d f}$ & Mean difference & \\
\hline DIM TOT & equal variances & .166 & .683 & -7.111 & 717 & $-8.00842^{* * *}$ & In favour of posttest \\
& No equal variances & & & & -7.114 & 711.224 & -8.00842 & \\
\hline
\end{tabular}

*** Significant difference at $1 \%(\mathrm{p}<0.01)$

Table 5. Results in the aggregated dimension (Student's t-test).

\subsection{Comparison of mean difference for the evaluation of the impact by dimension}

A one factor Analysis of Variance was performed with the opinion item (item 21) and with dimensions 1, 2, 3 and 4 . The results indicate that the differences are significant in favour of the posttest. See Table 7.

The two-factor analyses of variance reveal significant differences in all of the dimensions and in the item criterion in favour of the posttest, as well as significant differences between courses. 


\begin{tabular}{llllll}
\hline Origin & Type III sum of squares & df & Root mean square & F & Significant direction \\
\hline Group & 10160.547 & 1 & 10160.547 & 46.732 & In favour of posttest*** \\
Course & 13064.114 & 10 & 1306.411 & 6.009 & In favour of posttest*** \\
Group * Course & 4146.474 & 10 & 414.647 & 1.907 & In favour of posttest** \\
\hline
\end{tabular}

$\mathrm{R}$ squared $=.186$ (adjusted $\mathrm{R}$ squared $=.156$ )

**Significant difference at $5 \%(\mathrm{p}<0.05)$

***Significant difference at $1 \%(\mathrm{p}<0.01)$

Table 6. Results for the aggregated dimension (two-factor ANOVA).

\begin{tabular}{|c|c|c|c|c|c|c|}
\hline & & Sum of squares & df & Root mean square & $\mathbf{F}$ & Significant direction \\
\hline \multirow[t]{3}{*}{ ITEM 21} & Inter-group & 59.332 & 1 & 59.332 & 53.005 & In favour of posttest ${ }^{* * *}$ \\
\hline & Intra-group & 838.415 & 749 & 1.119 & & \\
\hline & Total & 897.747 & 750 & & & \\
\hline \multirow[t]{3}{*}{ DIM 1} & Inter-group & 1139.147 & 1 & 1139.147 & 69.129 & In favour of posttest*** \\
\hline & Intra-group & 12326.001 & 748 & 16.479 & & \\
\hline & Total & 13465.148 & 749 & & & \\
\hline \multirow[t]{3}{*}{ DIM 2} & Inter-group & 568.687 & 1 & 568.687 & 34.964 & In favour of posttest $t^{* * *}$ \\
\hline & Intra-group & 12019.931 & 739 & 16.265 & & \\
\hline & Total & 12588.618 & 740 & & & \\
\hline \multirow[t]{3}{*}{ DIM 3} & Inter-group & 1095.207 & 1 & 1095.207 & 45.159 & In favour of posttest*** \\
\hline & Intra-group & 18068.073 & 745 & 24.252 & & \\
\hline & Total & 19163.280 & 746 & & & \\
\hline \multirow[t]{3}{*}{ DIM 4} & Inter-group & 352.284 & 1 & 352.284 & 19.081 & In favour of posttest*** \\
\hline & Intra-group & 13754.415 & 745 & 18.462 & & \\
\hline & Total & 14106.699 & 746 & & & \\
\hline
\end{tabular}

Table 7. Results for the opinion item and for the dimensions (one-factor ANOVA).

The cross effects between course and group (pretest/posttest) are significant. The only dimension that shows a non-significant interaction between courses and pretest and posttest is dimension 2. Tables $\mathbf{8 - 1 2}$ show these results.

\subsection{Comparison of mean difference for the study of impact by course.}

Student's t-comparisons for mean differences were performed between the pretest and posttest (independent samples). Prior to this, Levene's test for matching variables was performed.

Table 13 shows the results obtained from the analysis of significance of the mean difference by course. 


\begin{tabular}{llllll}
\hline & Type III sum of squares & df & Root mean square & F & Significant direction \\
\hline COURSE & 35.144 & 10 & 3.514 & 3.209 & In favour of posttest*** \\
GROUP & 59.409 & 1 & 59.409 & 54.243 & In favour of posttest*** \\
COURSE * GROUP & 22.579 & 10 & 2.258 & 2.062 & In favour of posttest** \\
\hline
\end{tabular}

$\mathrm{R}$ squared $=.158$ (adjusted $\mathrm{R}$ squared $=.128)$

**Significant difference at $5 \%(\mathrm{p}<0.05)$

***Significant difference at $1 \%(\mathrm{p}<0.01)$

Table 8. Results for the opinion item (two-factor ANOVA).

\begin{tabular}{|c|c|c|c|c|c|}
\hline & Type III sum of squares & df & Root mean square & F & Significant direction \\
\hline COURSE & 716.675 & 10 & 71.668 & 4.542 & In favour of posttest $t^{* * *}$ \\
\hline GROUP & 1031.545 & 1 & 1031.545 & 65.374 & In favour of posttest $t^{* * *}$ \\
\hline COURSE* GROUP & 399.861 & 10 & 39.986 & 2.534 & In favour of posttest ${ }^{* * *}$ \\
\hline
\end{tabular}

$\mathrm{R}$ squared $=.193$ (adjusted $\mathrm{R}$ squared $=.165$ )

${ }^{* * *}$ Significant difference at $1 \%(\mathrm{p}<0.01)$

Table 9. Results for dimension 1 (two-factor ANOVA).

\begin{tabular}{llllll}
\hline & Type III sum of squares & df & Root mean square & F & Significant direction \\
\hline COURSE & 1022.919 & 10 & 102.292 & 6.608 & In favour of posttest $t^{* * *}$ \\
GROUP & 429.853 & 1 & 429.853 & 27.767 & In favour of posttest $t^{* * *}$ \\
COURSE * GROUP & 224.897 & 10 & 22.490 & 1.453 & \\
\hline
\end{tabular}

$\mathrm{R}$ squared $=.165$ (adjusted $\mathrm{R}$ squared $=.135$ ).

${ }^{* * *}$ Significant difference at $1 \%(\mathrm{p}<0.01)$

Table 10. Results for the dimension 2 (two-factor ANOVA).

\begin{tabular}{llllll}
\hline & Type III sum of squares & df & Root mean square & F & Significant direction \\
\hline COURSE & 1071.702 & 10 & 107.170 & 4.639 & In favour of posttest*** \\
GROUP & 1028.217 & 1 & 1028.217 & 44.505 & In favour of posttest*** \\
COURSE * GROUP & 379.556 & 10 & 37.956 & 1.643 & In favour of posttest \\
\hline
\end{tabular}

$\mathrm{R}$ squared $=.156$ (adjusted $\mathrm{R}$ squared $=.127)$

*Significant difference at $10 \%(\mathrm{p}<0.10)$

***Significant difference at $1 \%(\mathrm{p}<0.01)$

Table 11. Results for the dimension 3 (two-factor ANOVA). 


\begin{tabular}{llllll}
\hline & Type III sum of squares & df & Root mean square & F & Significant direction \\
\hline COURSE & 1117.229 & 10 & 111.723 & 6.454 & In favour of posttest*** \\
GROUP & 428.835 & 1 & 428.835 & 24.773 & In favour of posttest*** \\
COURSE * GROUP & 342.801 & 10 & 34.280 & 1.980 & In favour of posttest** \\
\hline
\end{tabular}

R squared $=.149$ (adjusted R squared $=.120$ )

**Significant difference at $5 \%(\mathrm{p}<0.05)$

$* *$ Significant difference at $1 \%(\mathrm{p}<0.01)$

Table 12. Results for dimension 4 (two-factor ANOVA).

\begin{tabular}{|c|c|c|c|c|c|}
\hline Course & Opinion item & DIM 1 & DIM 2 & DIM 3 & DIM 4 \\
\hline$\overline{\mathrm{BM}}$ & ** & & & $*$ & \\
\hline $\mathrm{BIO}$ & & * & & & $* *$ \\
\hline SPPA & $* * *$ & $* * *$ & * & * & * \\
\hline AUD & $* *$ & $* * *$ & $* *$ & * & \\
\hline LAW & $* * *$ & $* * *$ & $* * *$ & $* * *$ & $* * *$ \\
\hline $\mathrm{DES}+\mathrm{FA}$ & * & $* *$ & $* *$ & & \\
\hline EDU & & $* * *$ & $* * *$ & $* * *$ & $* * *$ \\
\hline \multicolumn{6}{|c|}{ BM + LAW (EXC) } \\
\hline PHY & * & $* *$ & & $* *$ & \\
\hline INF & & * & & & \\
\hline MAR & & $* *$ & & $* *$ & \\
\hline JOU & & * & & & \\
\hline MAR & $* * *$ & $* * *$ & $* *$ & $* * *$ & $* * *$ \\
\hline
\end{tabular}

*Significant differences at the 0.10 level of significance **Significant differences at the 0.05 level of significance ***Significant differences at the 0.01 level of significance

Table 13. Summary of significant differences in each dimension by course.

At a $10 \%$ significance level, the SREU module appears not to have any effect on BM + Law (Excellens). With Computer Science and Journalism students, the teaching of the SREU module seems to have a significant impact at a 10\% level. With the Marketing, SPPA and Law courses there seems to be an impact on the students in all of the dimensions and in the opinion item.

Dimensions 1 (Commitment to others and my surroundings) and 3 (Education in social responsibility) seem to have the greatest impact among the students, especially in dimension 1. Dimension 4 (Approaching my professional activity from a position of social commitment) is the one that generally has the smallest impact among the students. 
The social responsibility module appears to have an impact on students' commitment to others and their surroundings (DIM 1), except in the BM courses and the BM + LAW (Excellens) double degree. Discovering values (DIM 2) seems to be reinforced after taking the module in courses that are related to creativity such as Audiovisual Communication, Marketing, Fine Arts and Design and Pre-school and Primary Education. There also appears to be an impact in courses such as Law and Sport and Physical Activity Sciences where values play a very important role in the exercise of the profession. This hypothesis is reinforced by the impact that approaching their professional activity from a position of social commitment (DIM 4) has for the students. This impact is also present among students of Biotechnology, Teaching and Marketing.

For students of Business Management, Audiovisual Communication, Physiotherapy, and Fine Arts and Design, while the experience of taking the module appears not to have had an impact in all dimensions, at a general level it does seem to have had an impact on their capacity for commitment and social responsibility. Students of teaching did experience a change in commitment, in discovery of values (DIM 2), in training in social responsibility (DIM 3) and in approaching their professional activity from a position of social commitment (DIM 4). They do not however seem to experience a change at a general level in their commitment and social responsibility. This could be explained by the students being capable of identifying each nucleus or dimension separately, but at an overall level believing that their commitment and responsibility has not changed significantly.

\section{Discussion of results and conclusions}

The Student Social Responsibility module delivered at the UFV seems to have a positive general impact on the students. The results show significant differences in the aggregated dimension (general) made up of students' commitment to others and their surroundings, personal discovery of values, training in social responsibility and approaching professional activity from a position of social commitment. This demonstrates its impact on students' capacity for commitment and on their social responsibility after the experience of taking the module. It also seems to be clear that this impact differs between courses.

The analysis by dimensions indicates that each of the dimensions, separately, has an impact on the students. The students' commitment, discovery of values, training in social responsibility and approaching professional activity from a position of social responsibility are reinforced after taking the module. Also, in general terms, their commitment and social responsibility improve after taking the module. There is a difference in impact after taking the module depending on the course, except in personal discovery of values where no significant differences were found in the comparison between the pretest and posttest on the different courses.

The impact by course of the module shows that the results do differ depending on the course.

The only course where taking the SREU module does not appear to have an impact is BM + Law (Excellens). In the Journalism, Law and SPPA courses, taking the module has a positive impact 
on students' commitment to others and their surroundings, values, social responsibility, professional approach and overall social commitment.

Taking the module appears to have a positive impact in virtually all of the courses (except BM and BM + Law) in students' commitment to others and their surroundings. Nonetheless, the professional approach from a position of social commitment after taking the module only seems to be positively affected in Biotechnology, SPPA, Law, Education and Marketing.

In summary, the results indicate that taking the social responsibility module has a significant impact on students from the UFV in general and by dimensions and courses but that this impact differs by course.

\section{A. Appendices}

SREU questionnaire (Values from 1 to 6 with 1 indicating minimal agreement and 6 maximum agreement)

Dimension 1. Commitment to others and my surroundings

1. I have an overview of the current situation of the world and I am conscious of the urgent need for sustainable development.

2. This consciousness increases my interest as a student in contributing to improving my immediate environment.

3. I ask myself what my personal position is faced with social injustice and other people's suffering.

4. I put into practice my ability to serve and my commitment to immigrants, disabled people, homeless people, deprived children, the elderly, etc.

5. I think that one of my obligations as a person is to help others, from a position of social commitment.

\section{Dimension 2. Personal discovery of values}

6. I believe that social commitment is based on recognising and respecting the dignity of every individual.

7. I recognise the need to open myself up to others, put myself in their place and find common good above individualistic interests.

8. I believe that personal change is a necessary prior step to change the world around me.

9. I have personally experienced the happiness that comes from service and solidarity.

10. I believe that the experience of giving oneself to others is helpful for discovering personal values.

\section{Dimension 3. Education in social responsibility}

11. I believe that being a student helps me be aware of the importance of social responsibility.

12. I have reflected on the importance of not remaining indifferent to or detached from what happens to other people.

13. I believe that the more I study in-depth and work hard at university, the more I can contribute to social change.

14. The training I receive at university will contribute in practice to increasing my level of social responsibility.

15. I believe that social responsibility is a competence that should be worked on at university.

Dimension 4. Approaching my professional activity from a position of social commitment

16. I approach performing my future professional activity wth a service vocation directed at the common good. 
17. I believe that good professional practice requires commitment, team work, perseverance, empathy, tolerance, integrity and respect.

18. I think my personal fulfilment and happiness rely on me being a professional committed to the continuous improvement of society.

19. I believe that the action of a good professional has an impact on his or her immediate surroundings and on other areas of greater transcendence.

20. I think it is realistic to say that social commitment is possible through one's professional activity.

Opinion item

21. To summarise, evaluate how much you feel committed and socially responsible at this time.

\section{Author details}

José Manuel García Ramos*, Carmen de la Calle Maldonado², María Consuelo Valbuena Martínez ${ }^{2}$ and Teresa de Dios Alija ${ }^{2}$

*Address all correspondence to: jmgramos@ucm.es

1 Department of Research Methods and Educational Analysis, Faculty of Education, Complutense University of Madrid, Spain

2 Universidad Francisco de Vitoria, Spain

\section{References}

[1] DeDios-Alija T. Responsabilidad de la persona y sostenibilidad de las organizaciones. Madrid: Francisco de Vitoria University; 2014

[2] Pascarella ET, Ethington CA, Smart JC. The influence of college on humanitarian/civic investment values. Journal of Higher Education. 1988;59;412-437

[3] Galán JI. Reflexiones sobre la responsabilidad social corporativa en el siglo XXI. Salamanca: Ediciones Universidad de Salamanca; 2012

[4] Astin AJ, Sax L, Avalos J. Long term effects of volunteerism during the undergraduate years. The Review of Higher Education. 1999;22(2):187-202

[5] Reason RD, Ryder AJ, Kee C. Higher education's role in educating for personal and social responsibility: A review of existing literature. New Directions for Higher Education. 2013; 164:13-22

[6] Hernandez De Hahn L. Socially responsible citizens: Promoting gifts and talents that support social and humanitarian advancement. International Studies in Sociology of Education. 2014;24(4):415-434 
[7] Sánchez González CL, Herrera Márquez AX, Zárate Moreno LG, Moreno Méndez W. La responsabilidad social universitaria (RSU) en el contexto del cambio de educación superior. Mexico City: Universidad Autónoma De México; 2007

[8] de la Calle C, García Ramos JM, Giménez P, Ortega, M. Validación y medida de la responsabilidad social en la Universidad. Revista Complutense de Educación. 2008;19(2)

[9] Larrán Jorge M, Andrades Peña FJ. La oferta de asignaturas de responsabilidad social corporativa y ética empresarial en las titulaciones de finanzas y contabilidad: análisis comparativo con el ámbito de la gestión de organizaciones. Revista de contabilidad. 2015;18(1):1-10

[10] Lappalainen P. Development cooperation as methodology for teaching social responsibility to engineers. European Journal of Engineering Education. 2011;36(6):513-519

[11] Gordon B, Doyle S. Teaching personal and social responsibility and transfer of learning: Opportunities and challenges for teachers and coaches. Journal of Teaching in Physical Education. 2015;34:152

[12] Buyolo F. Humanizar la empresa. Hacia una formación empresarial ética. Bubok Publishing S.L; 2015

[13] Robledo Ramón P, Fidalgo Redondo R, Arias Gundín O, Álvarez Fernández L. Percepción de los estudiantes sobre el desarrollo de competencias a través de diferentes metodologías activas. Revista de Investigación Educativa. 2015;33(2):369-383

[14] García Cabrera M, González López I, Mérida Serrano R. Validación del cuestionario de evaluación ACOES. Análisis del trabajo cooperativo en Educación Superior. Revista de Investigación Educativa. 2012;30(1):89-107

[15] López Quintás A. Inteligencia creativa: El descubrimiento personal de los valores. Madrid: Biblioteca De Autores Cristianos; 2003

[16] de la Calle C, García Ramos JM, Giménez P. La formación de la responsabilidad social en la Universidad. Revista Complutense de Educación. 2007;18(2)

[17] García Ramos JM, de la Calle C, Valbuena MC, DeDios-Alija T. Hacia la validación del constructo "Responsabilidad Social del Estudiante Universitario" (RSEU). Bordon. 2015; 68(1):153-170 
